\title{
ArcheoSciences
}

Revue d'archéométrie

\section{From the goldsmith's point of view}

Gilding on metals during the first millennium AD - techniques and their development in the Germanic area

Du point de vue de l'orfèvre : dorure sur métal au premier millénaire apr.J.-C.les techniques et leur évolution dans l'aire germanique

\section{Iris Aufderhaar}

\section{(2) OpenEdition}

\section{Journals}

Electronic version

URL: http://journals.openedition.org/archeosciences/2269

DOI: 10.4000/archeosciences.2269

ISBN: 978-2-7535-1598-7

ISSN: $2104-3728$

\section{Publisher}

Presses universitaires de Rennes

\section{Printed version}

Date of publication: 31 December 2009

Number of pages: $243-253$

ISBN: 978-2-7535-1181-1

ISSN: 1960-1360

\section{Electronic reference}

Iris Aufderhaar, «From the goldsmith's point of view », ArcheoSciences [Online], 33 | 2009, Online since 10 December 2012, connection on 01 May 2019. URL : http://journals.openedition.org/

archeosciences/2269; DOI : 10.4000/archeosciences.2269 


\title{
From the goldsmith's point of view: gilding on metals during the first millennium $\mathrm{AD}$ - techniques and their development in the Germanic area
}

\author{
Du point de vue de l'orfêvre : dorure sur métal au premier millénaire apr. J.-C. - \\ les techniques et leur évolution dans l'aire germanique
}

\author{
Iris AufderhaAR*
}

\begin{abstract}
During the first millennium AD, gilding was of great importance for the decoration of ornaments in the Germanic area. With respect to archaeological finds, the different techniques used to produce them are hard to distinguish without scientific investigations. Nevertheless, it is possible to put forth some hypotheses regarding these methods on the basis of the analyses carried out so far, and the observation of typical attributes, like workmanship and choice of material.

The gilding techniques used for some fibulae and brooches are analysed exemplarily, and discussed together with the advantages and disadvantages related to their specific attributes, and changes in their technique and design during the first millennium AD. In addition, the supply of raw materials and the correlations between gold imports into the Germanic area and the amount of gilded material are discussed.
\end{abstract}

Résumé : La dorure était une technique majeure de décoration d'ornements dans l'aire germanique au premier millénaire AD. Les diverses techniques employées dans la production des trouvailles archéologiques sont difficiles à différencier sans une étude scientifique. Néanmoins, il est possible d'avancer quelques hypothèses sur ces techniques, en se basant sur des analyses réalisées jusqu'à présent et l'observation de caractéristiques précises comme l'exécution et le choix du matériel.

Les techniques de dorure utilisées dans la fabrication de fibules et broches pendant le premier millénaire AD sont ici analysées et discutées, en ce qui concerne les avantages et désavantages correspondant à leurs caractéristiques spécifiques et aux changements techniques et stylistiques. En plus, les approvisionnements en matière première et les corrélations entre les importations d'or dans l'aire germanique, ainsi que la quantité de matériel doré, sont discutés.

Keywords: Gilding, gold work, brooch, Roman Iron Age, Migration Period, Merovingian Period.

Mots-clés : Dorure, travail de l'or, broche, Âge du Bronze romain, Migrations, Mérovingien.

\footnotetext{
* Niedersächsisches Institut für historische Küstenforschung, Lower Saxony Institute for Historical Coastal Research - Viktoriastraße 26-28, 26382 Wilhelmshaven, Germany. (aufderhaar@nihk.de)
} 


\section{INTRODUCTION}

During the first millennium AD, gilding was of great importance for the decoration of ornaments in the Germanic area. The diffusion bonding method was verified on several items from the Late Roman Iron Age in Germany and Norway (Becker, 2002a; b; Becker et al., 1996a; b; 1998; von Carnap-Bornheim, 2006: 91; Füting, 2001; Plather $e t$ al., 1995; Plather and Siemensen, 2002) around the middle of the 1990s, and represented an addition to the three gilding techniques that were known for the Germanic area until that date: plating, leaf gilding, and fire gilding.

In most of the goldsmith workshops in existence today, those ancient techniques were replaced by electro-gilding; however, some of them, like fire gilding, are carried out on rare occasions. Leaf gilding is mainly used for the decoration of non-metallic items.

With respect to archaeological finds, the different techniques used to produce them are difficult to distinguish without scientific investigations. Nevertheless, it is possible to put forth some hypotheses regarding these methods on the basis of the analysis carried out so far, and the observation of typical attributes, like workmanship, as well as the choice and thickness of the material.

\section{GILDING TECHNIQUES}

The term 'plating' is used for a variety of techniques having in common a feature in which the gold foil is fixed mechanically to a substructure by flanging or punch marks, as well as by gluing it to the base (Fig. 1). Some disadvantages of these techniques are the weak connection between the components, which cannot prevent a corrosion of the base, and the high quantity of gold required by the comparably thick foils (von Carnap-Bornheim, 2006: 89f; Ebert, 1929: 131; Hammer, 1998: 190; Hammer and Voß, 1998: 325; Oddy, 1993: 172f).

In contrast, the advantage of leaf gilding is the relatively small and easily measurable amount of gold required. On archaeological objects, the gold foils that were attached to a substructure coated with glue (Fig. 1) and considered as gold leafs were only up to $6 \mu \mathrm{m}$ thick (von Carnap-Bornheim, 2006: 88f; Hammer, 1998: 190ff; Hammer and Voß, 1998: 315). On objects like ornaments, whose surface is frequently touched, a thin coating and a bond based on glue are less suitable because they can be easily removed (Aufderhaar, 2005: 8).
The diffusion bonding method (Fig. 1) is based on the natural diffusion process of atoms, which can be accelerated by heating at a temperature of about $300{ }^{\circ} \mathrm{C}$. A thin diffusion layer is formed between two metal surfaces that are in close contact, causing a bond that provides a long lasting and even gilding of high quality and with good resistance to corrosion. A detailed description of the gilding process is included in the book De Diversis Artibus, written in the $12^{\text {th }}$ century $\mathrm{AD}$ by the monk and goldsmith Theophilius Presbyter (Brepohl, 1987: 236): after gilding had already been executed on thicker material, the gilded silver plate was hammered to foil and embossed (von CarnapBornheim, 2006: 91; Hammer, 1998: 189ff; Hammer and Voß, 1998: 316f; Oddy et al., 1981: 240; Riederer, 1987: 90). According to the description, this technique is mainly suitable for the gilding of foils, but hardly for objects that are already produced in a certain shape, like cast items (Becker et al., 1996b: 58f), or for objects with deeply profiled surfaces, where the gold foils can hardly be attached neatly enough, as well as for gilding copper alloys, because the quick oxidation of copper exposed to heat prevents the development of a diffusion layer (Anheuser, 1999: 8). With coatings between 8 and $20 \mu \mathrm{m}$ as detected on archaeological objects, this method requires a slightly higher quantity of gold than leaf gilding (Becker, 2002a: 29; Becker, 2002b; Hammer, 1998: 191f). In addition to this repeated heating, other procedures, such as annealing processes or soldering, can lead to the finishing of the gilding on silver.

The process of fire gilding is also based on the diffusion of metal atoms. In this case, gold and mercury are mixed into an amalgam which is distributed evenly on the surface of the object (Fig. 1). The mercury in the amalgam supports and accelerates the diffusion between substructure and coating; it evaporates from the coating at temperatures between 250 and $350^{\circ} \mathrm{C}$, leaving only a very small but characteristic amount of mercury of 5 to $25 \%$ in the gold coating (Anheuser, 1999: 34; Aufleger, 1996: 628; Brepohl, 1987: 111; 2003: 401ff; Bühler, 1998/1999: 443f; von CarnapBornheim, 2006: 90f; Hammer, 1998: 192f; Hammer and Voß, 1998: 325; Lins and Oddy, 1975: 370; Roth, 1986: $54 \mathrm{ff}$ ). On the basis of the amalgam paste, fire gilding is not only suitable for copper alloys, but also for items with deeply profiled and uneven surfaces, as well as cast objects (Becker et al., 1998: 207f). In addition to the comparably high quantity of gold required, due to coatings with a thickness of up to $100 \mu \mathrm{m}$ (Hammer, 1998: 191, 193), the other main disadvantage of this technique results from the use of mercury: to date, there is no archaeological or historical evidence that the cinnabar deposits in the Germanic area were exploited for the distillation of mercury before the Middle 


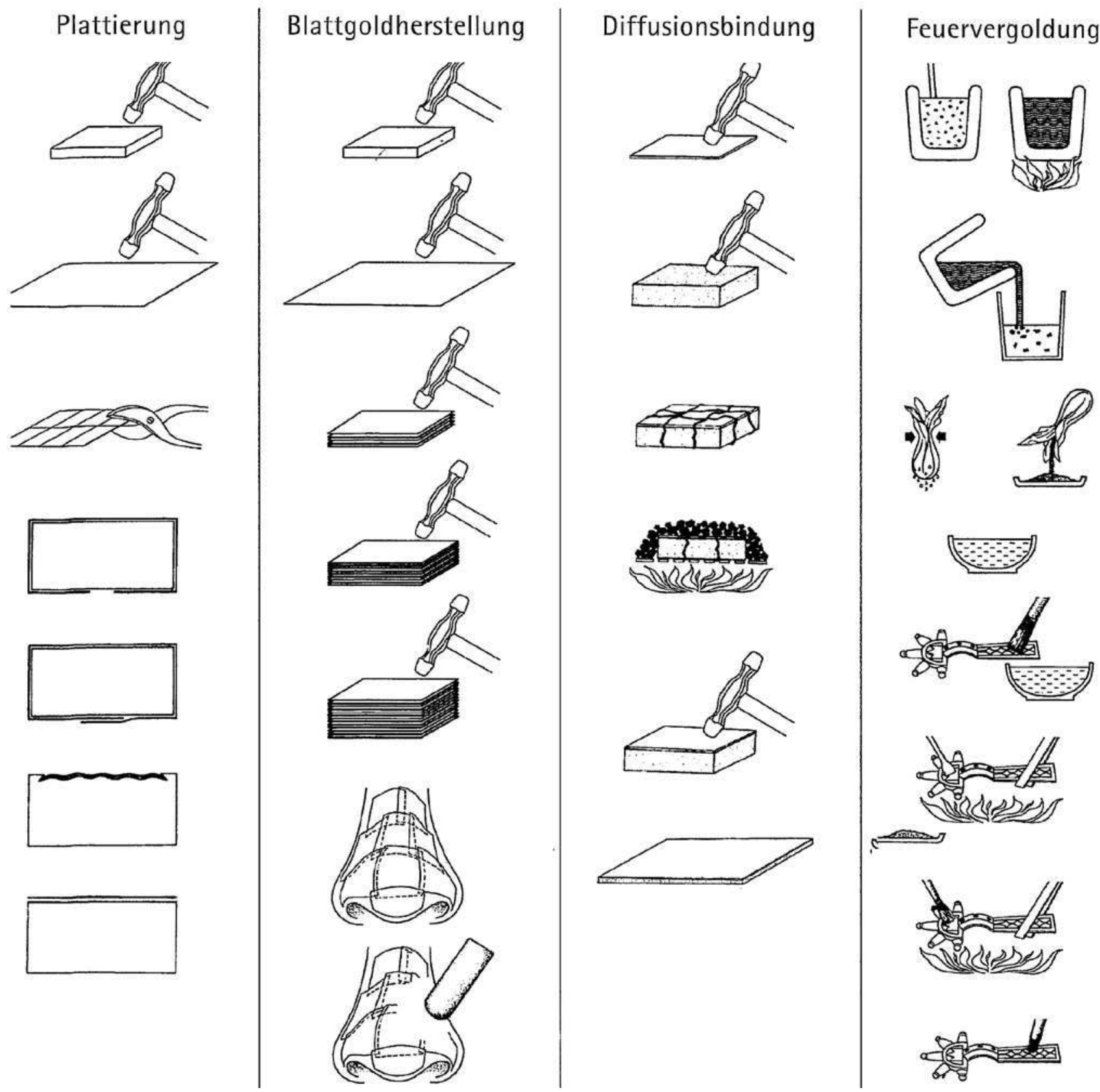

Figure 1: Schematic illustration of gilding techniques: plating, leaf gilding, diffusion bonding and fire gilding (von Carnap-Bornheim, 2006, Fig. 1).

Figure 1 : Illustration schématique des techniques de dorure: placage, dorure à la feuille, mise en couleur et dorure à l'amalgame (von CarnapBornheim, 2006, Fig. 1).

Ages (Anheuser, 1999: 17; Weisgerber, 2003: 10; 2007). It can also be assumed that another possibility to obtain mercury was trade, for example with the Roman Empire (Becker et al., 1998: 208f), and later on with the Byzantine Realm. As mercury was not an easily obtainable raw material, the idea that gilders were searching for an adequate replacement seems reasonable. Several arguments can be mentioned arguing against the theory developed by B. Arrhenius (1964: 38f; Arrhenius et al., 1968: 236; von Carnap-Bornheim, 1994: 101), that during the Vendel and Viking Ages, resin instead of mercury was used for fire gilding: resin chars during heating and would rather prevent a diffusion of the 
gold into the substructure than support it; additionally, the advantage of mercury in lowering the melting point would be lost (Anheuser, 1999: 16). Resin would be more likely fit for gluing gold onto an object.

At first sight, the method entailing the replacement of mercury with lead in fire gilding seems more practicable, as proposed by A. Oldeberg (1966: 187). A similar description is preserved in the Leyden Papyrus X, a collection of receipes from the $3^{\text {rd }}$ or $4^{\text {th }}$ century $\mathrm{AD}$ (Raub, 1993: 104): gold and lead are ground together, mixed with gum serving as an adhesive, and distributed on the object to be gilded (Caley, 1926: 1156, here referred to as receipe 38; Halleux, 2002: 94, here referred to as receipe 37). According to the translation by E.R. Caley (1926: 1156), the lead was supposed to be consumed by heat, and thus evaporate, like mercury. As the boiling point of lead at $1750^{\circ} \mathrm{C}$ is considerably higher than the melting point of gold $\left(1057^{\circ} \mathrm{C}\right)$ or those of materials like silver $\left(950^{\circ} \mathrm{C}\right)$ or coppee $\left(1084^{\circ} \mathrm{C}\right)$, a vaporization of the lead is not feasible (Aufderhaar, 2009: 33f; discussion with S. Greiff, RGZM). Since some receipes of the Papyrus Leyden X contain inaccurate descriptions, K. Anheuser (1999: 20f) put forth the hypothesis that the papyrus relies on the knowledge of craftsmen, but that the writer himself was most likely not one of them. Based on Caley's translation, C. Raub pointed out that it was not obvious if metallic lead was meant, and proposed that probably yellow lead oxide $(\mathrm{PbO})$ may have been used to dilute the gold particles and stick them to the object. As a variation, he considered that by heating the mixture of metallic lead and gold in an oxidising manner up to temperatures of more than $800{ }^{\circ} \mathrm{C}$, the lead would not alloy with the copper but oxidise to $\mathrm{PbO}$, flux the copper oxides and accordingly enable a diffusion of the gold (Raub, 1993: 104; see also von Lippmann 1919: 7).

R. Halleux (2002: 94) provided a new translation and another interpretation of the Leyden Papyrus X: according to it, the lead was not consumed by the heat, but liquefied. As the melting point of lead at $327^{\circ} \mathrm{C}$ is considerably lower than the one of gold, the lead was most likely meant to serve as a soft solder fixing a superficial gold layer to the copper object (Halleux, 2002: 174-175, remark 7). Gold and lead do not alloy but build up different intermetallic compounds influenced by the amount of lead in the mixture (Brepohl, 1987: 99ff; 2003: 29, 75; Wolters, 1981: 49).

\section{THE DEVELOPMENT OF GILDING ANALYSED ON THE EXAMPLE OF BROOCHES}

In addition to their practical function, fibulae and brooches also represented decorative elements of the garb, and therefore frequently became subject to decorations. This aspect makes them especially suitable for an exemplary analysis of changes in the technique and design of gilding. Furthermore, fibulae and brooches are types of ornaments presenting the greatest continuity, and are preserved in large numbers and numerous variations throughout the first millennium AD. Indeed, an analysis on the development of gilding can only be carried out exemplarily due to the huge amount of gilded material from this period; however, the number of fibulae that can be presented in this article is limited. The brooches discussed in this article are considered to be representative for groups of ornaments featuring the same characteristics in terms of their manufacturing process, type of decoration and choice of material.

In period B2 (Eggers, 1974) of the early Roman Iron Age, the predominant method of gilding was plating with gold sheets that were mechanically fixed to the object. One example of this is gold plating covering silver filigree: the embossed marks of the filigree work are reminiscent of decorations with gold wire known from some fibulae from period B1 (Eggers, 1974). Plated filigree is therefore a comprehensive decoration necessitating a lesser amount of gold (von Carnap-Bornheim, 1998: 467ff; 2006: 90). Some specimens belonging to fibulae of the Almgren types 27 to 30 (Almgren, 1973), found mainly in Jutland, Denmark, bear small scale stamped gold foil inlays (Cosack, 1979: 49ff, 98f; Nørling-Christensen, 1942). The evidence that a centre point was used for drilling the sockets for those inlays on a fibula from Quern-Scheersberg, Schleswig-Holstein, Germany (Fig. 2), and the decoration of the triangular inlays with fir branch-shaped punch marks indicate some technical influences from the Roman provinces (Bölckow, 2006: 66; Cosack, 1979: 49f).

During the late Roman Iron Age, the type of decoration with stamped foils was continued. The important innovation was the use of gilded silver sheets that were fixed to the substructure of the given ornament. The advantage of this technique was that it required a smaller amount of gold. A polychrome design was achieved by various combinations of methods, and decorations range from simple collars of gilded foil attached to the bow of a fibula, like on an example from the $3^{\text {rd }}$ century burial in Gommern, Saxony-Anhalt, Germany (Becker, 2001: 131f), to rather complex combinations of gilded foils, silver elements such as small rivets, and rims and glass inlays, like on the Scandinavian rosette brooches (Almgren, 1973: group VII), or on brooches of type Mackeprang IX (Eggers, 1964: 37f; Ethelberg, 2000: 51f; Lund Hansen, 1971; Lund Hansen et al., 1995: 212f). Diffusion bonding was scientifically identified as a gilding technique on the foil collar of the fibula from the Gommern 


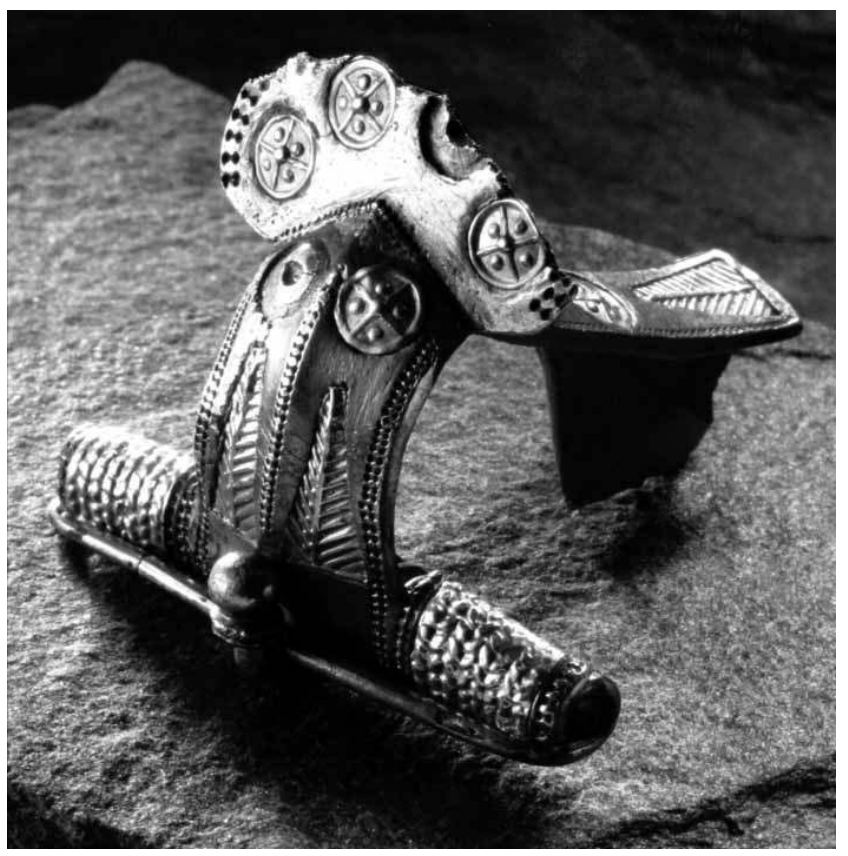

Figure 2: (See colour plate) Silver fibula with gold inlays and plated filigree work from Quern-Scheersberg, Schleswig-Holstein, Germany (Bölckow, 2006: 67).

Figure 2: (Voir planche couleur) Fibule en argent avec des inclusions d'or et du filigrané plaqué, de Quern-Scheersberg, Schleswig-Holstein, Allemagne (Bölckow, 2006: 67).

burial (Becker, 2002a; b; Becker et al., 1996a; b; 1998), and on the fragments of two rosette brooches from Norway: the bonding was achieved by hammering the gold foil to the silver plate and subsequently heating both components. On two other Norwegian rosette brooches, evidence that the bonding was supported by a copper-bearing solder was found (Plather et al., 1995: 12ff; Plather and Simensen, 2002: 547ff).

The design of the disc brooches follows the same principles, using gilded and stamped silver foils, silver elements, and sometimes glass inlays. Since diffusion bonding had already been carried out before hammering the metal, the foils must have been stamped after the gilding, but some of the disc brooches show traces of a fire gilded surface. The production of chased foil, like on the disc brooch from Tangendorf, Lower Saxony, Germany (Fig. 3), with its elaborate representation of a deer (Brandt, 2006: 70; Drescher, 1955: 25ff), or other intensely curved foils, like on tutulus shaped brooches (Adomat, 2000: 411ff; Eichhorn, 1908: 903ff; Ethelberg, 2000: 312f; Thomas, 1966: 103) requires repeated annealing processes, as the distortion of precious metals through techniques such as hammering or embossing

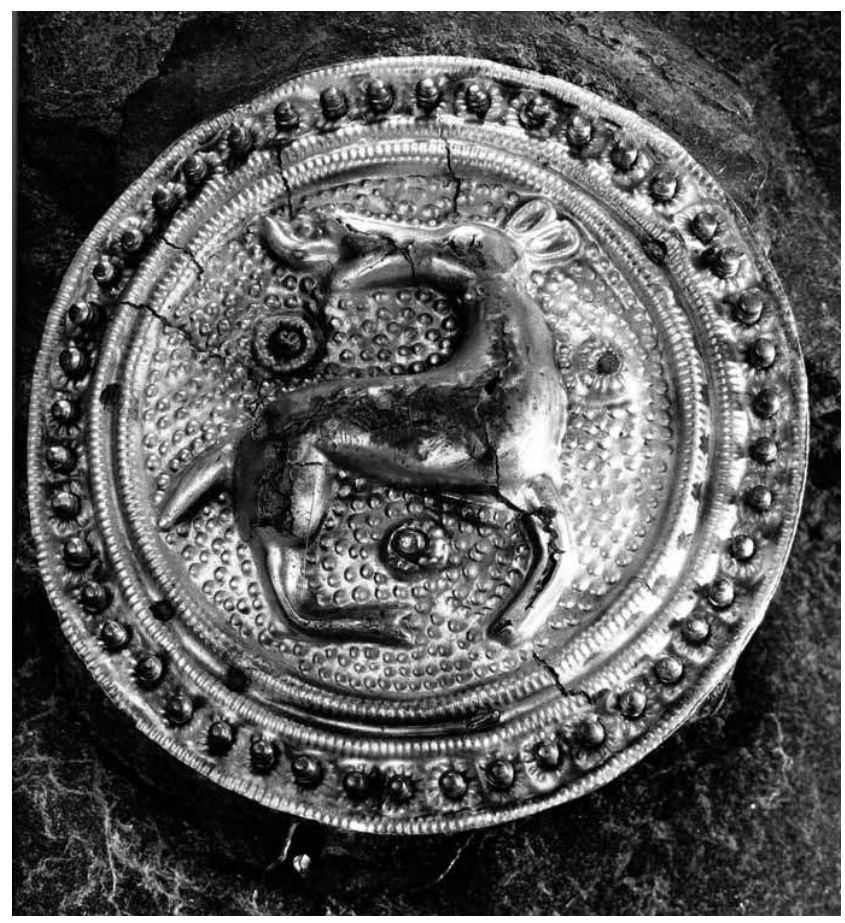

Figure 3: (See colour plate) Disc brooch from Tangendorf, Lower Saxony, Germany (Brandt, 2006: 71).

Figure 3: (Voir planche couleur) Broche discoide de Tangendorf, Basse Saxonie, Allemagne (Brandt, 2006: 71).

has to take place in a cold state. During such procedures, the crystal structure is forced into an unnatural condition; the metal hardens and can break under further distortion. In order to prevent this, precious metals are annealed after certain stages of distortion to achieve a re-crystallization of the structure and to regain their flexibility. The annealing process requires a minimal temperature of $200{ }^{\circ} \mathrm{C}$, but can also be carried out at higher temperatures (Brepohl, 2003: 184ff; Wolters, 1981: 26f). Silver that is already gilded would easily fade if heated several times. It is reasonable to assume therefore that the respective foils were gilded after curving by the technique of fire gilding. Scientific evidence that fire gilding was carried out during the Late Roman Iron Age was detected on the top of a silver shield boss from the aforementioned Gommern burial (Anheuser, 1999: 16; Becker et al., 1998: 207, 209; Bühler, 1998/1999: 444). The same argumentation is valid for gilded foils soldered to the substructure of the brooches.

From the times at the end of the Roman Iron Age and the Migration Period, several types of brooches are preserved that display gilding applied to more massive material, and in combination with several new decorative techniques, as for example on the silver bow brooches of the Wiesbaden 
type from the period between the end of the $4^{\text {th }}$ and the early $5^{\text {th }}$ century AD (Fig. 4), which are mainly distributed throughout the Middle Rhine Area. The decorations of those fibulae, carried out in niello and with punch marks as well as motifs like beaded string, are reminiscent of objects manufactured in the nearby Roman provinces during the late Roman Iron Age. Those objects can be considered as models for the decorations of the fibulae in terms of technique and ornamentation, as was already pointed out by Joachim Werner (1981). Mercury contents detected by spectral analysis on a closely related fibula from GroßKöris, Brandenburg, Germany (Fig. 5) support this thesis: fire gilding was carried out both on the thicker material of the foot, itself decorated by chip-carving, but also on silver foils mechanically attached to the bow of the fibula (Franke, 1987: 237ff; Gustavs, 1987: 215ff; Voß et al., 1998). Mercury contents on the surface of a gilded silver fibula from a grave find on the farm of Roligheten, Norway, represent yet another evidence of fire gilding during this period (Plather and Simensen, 2002: 548, 555).

Massive cast items gilded directly on their copper based alloys are found among the Saxon and Anglo-Saxon equal arm brooches and disc brooches, which are also decorated with elements deriving from the Roman provinces, like the

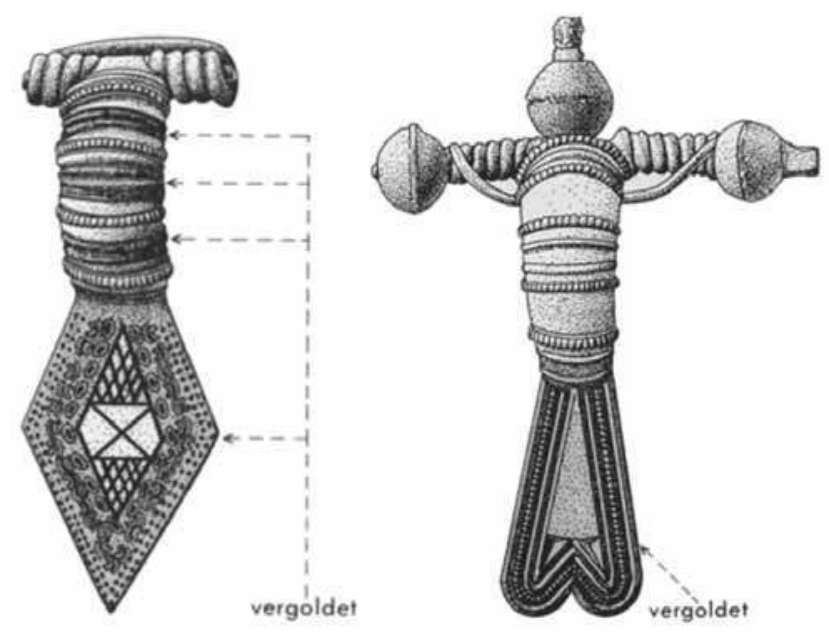

Figure 4: Fibulae of the Wiesbaden-type. Fibula from Wiesbaden, Hesse, Germany, decorated with niello inlays and punch marks, and fibula from Wulfen, Saxony-Anhalt, Germany, decorated with beaded string imitation (Werner, 1981: attachment 2, Figs. 15 and 1).

Figure 4 : Fibules de type Wiesbaden. Fibule de Wiesbaden, Hesse, Allemagne, décorée avec des inclusions de niello et marques de poinçonnage, Fibule de Wulfen, Saxonie-Anhalt, Allemagne, décorée avec des imitations de cordons perlés (Werner, 1981: document joint 2, Fig. 15 et 1).

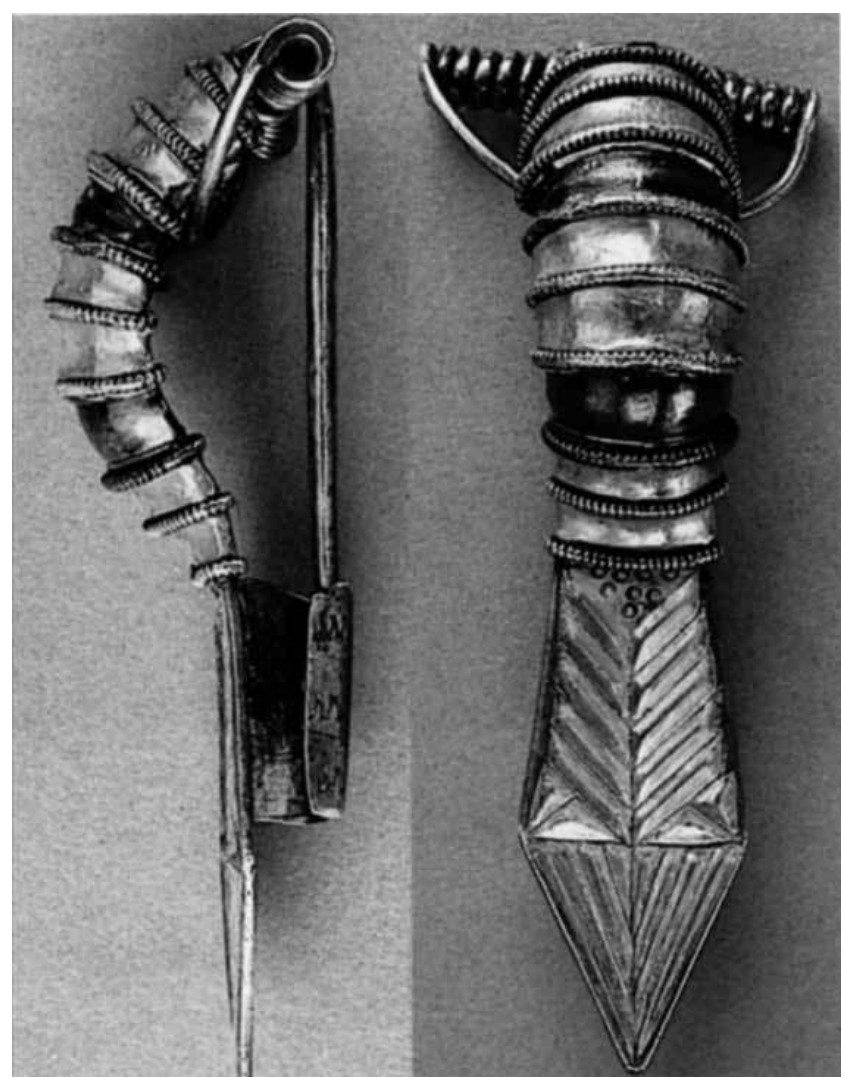

Figure 5: (See colour plate) Fibula decorated with chip-carving technique from Gross-Köris, Brandenburg, Germany (Voß et al., 1998: pl. 65b). Figure 5: (Voir planche couleur) Fibule décorée au moyen de la technique de chip-carving, de Gross-Köris, Brandebourg, Allemagne (Voß et al., 1998: pl. 65b).

egg and dart motif (Böhme, 1974: 14ff, 220; Bruns, 2003: 32, 57ff; Haselhoff, 1979: 153ff; Kühn, 1981: 64f). The only possible method for obtaining a durable gilding of those alloys is fire gilding.

Fire gilding was clearly established as the main gilding technique when the Germanic goldsmiths started to produce ornaments of more massive materials, like silver plate, or by casting of copper based alloys. These profound changes occurred together with the adoption of several techniques and decorative styles from metal objects manufactured in the Roman provinces during the end of the Roman Iron Age.

During the Migration and Merovingian Periods, the combination of decorative techniques (niello, chip-carving and fire gilding) on brooches cast of silver or copper alloy became a regular pattern for the decoration of the bow fibulae (Göldner, 1987; Koch, 1998).

In contrast, a unique phenomenon in the gilding of brooches during the first millennium $\mathrm{AD}$ is verified on some 
samples of small garnet brooches from the period between the end of the $5^{\text {th }}$ and the beginning of the $6^{\text {th }}$ century AD: while made of iron, the brooches were gilded by mechanically fixed gold or gilded silver sheets (Vielitz, 2003: 20ff, 162, 165, 207). Clearly, the technically challenging operation of fire gilding on iron, which requires a preliminary copper plating of the iron surface (Anheuser, 1999: 22; Hammer, 1998: 198), was not known or at least not carried out before then.

Gilded embossed foils were not abandoned as decorative elements, but were frequently used on disc brooches throughout the Migration and Merovingian Periods. While disc brooches bearing sockets or filigree decorations (Rademacher, 1940; Thieme, 1978) soldered to the foil, or brooches bearing copper alloy foils, must have been to be fire gilded, some of the disc brooches bearing stamped silver foils (Klein-Pfeuffer, 1993) could also have been gilded by diffusion bonding. To date, no analysis was carried out on those brooches, but a hint that the diffusion bonding method was not at all forgotten by the end of the Roman Iron Age is the detailed description provided in the $12^{\text {th }}$ century AD by Theophilius Presbyter (Brepohl, 1987: 236).

The number of gilded pieces among brooches increased considerably until the $6^{\text {th }}$ century $\mathrm{AD}$, and gilding of brooches was common during the Merovingian Period (Göldner, 1987; Koch, 1998; Kühn, 1981). From the end of the Merovingian Period onward, a clear decline in the amount of gilded material can be observed, which continued, at least on the continent, throughout the Carolingian Period. This development can be exemplified by the equal arm brooches manufactured between the beginning of the $7^{\text {th }}$ century AD and the Carolingian Period: only approximately $2 \%$ of the material was gilded (Thörle, 1998: 106f; 2001: 1, 5, 13, 309). Only very few gilded brooches are preserved from the Carolingian Period, and most of them are quite small objects, like bird shaped brooches or brooches with enamel inlays (Frick, 1992/1993; Haselhoff, 1990).

In Viking Age Scandinavia, the situation was quite different. A significantly higher number of brooches, like disc brooches (Jansson, 1984a; b) and oval brooches (Jansson, 1985), mainly made of copper based alloys, were gilded. After carrying out microscopic analysis on oval brooches, A. Oldeberg (1943: 270f; 1966: 186f) postulated that both leaf gilding and fire gilding were employed in their making.

The differences in the use and frequency of gilding during this period may have several reasons. In the Carolingian Empire, a significant number of brooches were made of tin or lead, metals not appropriate for fire gilding (Frick, 1992/1993). Furthermore, Viking Age Scandinavia also had the advantage of being able to purchase mercury because of its trade connections with the Byzantine Realm and Arabian countries.

\section{THE SUPPLY OF GOLD}

To date, there is only limited evidence regarding gold extraction in the Germanic area during the first millennium AD (Andersson, 1995: 11; Siegmund, 1998: 308). The only indications concerning placer gold mining in the Upper Rhine Area are the distinctive platinum and silver contents detected on gold objects from the Merovingian Period (Hartmann and Wolf, 1975: 23ff). Therefore, imports from the Roman Empire, and later from the East Roman and Byzantine Realm, are commonly considered to represent the source of the gold used in the Germanic area (Andersson, 1995: 11; Siegmund, 1998: 308). Nevertheless, evidence of gold imports is not readily available. In spite of this, there are some indications that the gold imports correspond quite well with the amount of gilded material. The first few gilded objects were from period B2 (Eggers, 1974) of the early Roman Iron Age, corresponding to a first increase of the gold imports into the Germanic area, which, after a brief caesura, continued during the Late Roman Iron Age (Andersson, 1995: 10; Roggenbuck, 1988: 55, 61). It is not evident in which form the gold was imported. F. Siegmund (1998: 308) suggests that imported gold coins served as raw material. His argument is supported by the finding of gold coins at the workshop site of Helgö, Sweden, bearing marks which may originate from testing the gold contents (Kyhlberg, 1986: 30).

In Denmark and Sweden, the amount of imported gold coins in deposits indicates an increasing import, which was interrupted after reaching its peak during the $5^{\text {th }}$ and $6^{\text {th }}$ centuries AD (Jørgensen and Vang Petersen, 1998: 279; Lund Hansen, 1987: 231). A shortage of precious metals from the middle of the $6^{\text {th }}$ century $\mathrm{AD}$ onwards becomes apparent in the Frankish Realm as well, as golden ornaments became scarce in Middle and Northern Europe (Siegmund, 1998: 212). In addition, examinations carried out by J.P.C. Kent (1972: 70ff) on Merovingian gold coins indicate a reduction of the gold contents from $90-100 \%$ down to $30 \%$ during the period between the end of the $6^{\text {th }}$ and the beginning of the $7^{\text {th }}$ century AD. They were finally replaced by silver coins at the end of the $7^{\text {th }}$ century $\mathrm{AD}$. The considerable decrease of gilded objects from the $7^{\text {th }}$ century $\mathrm{AD}$ onwards follows this tendency, showing however a certain delay. For Viking Age Scandinavia, an increase in gold imports can be observed from the amount of gold ornaments and deposits (Jørgensen and Vang Petersen, 1998: 286), which once again corresponds to the amount of gilded material. 


\section{Conclusions}

Addressing the reasons for the development of gilding techniques, it can be assumed that the shift from plating to diffusion bonding was most likely caused by an effort to save gold. Nevertheless, this argument is not appropriate for explaining the success of fire gilding, because in that case the gold layer is considerably thicker than those produced by diffusion bonding. In addition to this, fire gilding required not only gold, but also mercury, as raw material. The success of the fire gilding method is therefore most likely related to its more comprehensive applicability, associated with a high quality of the gilding. It represented the best technique for gilding massive or deeply profiled objects, and pieces made of copper alloys. Nevertheless, it is premature to set a limit for the diffusion bonding method to the Roman Iron Age.

The development of gilding was influenced by several factors. The coherence of gilded material with the amount of gold available in the Germanic territories is noticeable. One other influence was related to developments in the manufacturing of jewellery. This meant that the technique that was most suitable for a given type of ornament was used more frequently. During the early Roman Iron Age, the use of gilded and stamped silver foils enabled a production of a larger amount of similar decorative elements without a considerably higher use of gold (von Carnap-Bornheim, 2006: 92.). The fire gilding method opened up new possibilities for the mass production of gilded ornaments, because it was suitable for gilding cast objects. Influences from the Roman Empire were most likely another factor having an impact on further developments: evidently, changes in gilding techniques occurred contemporarily with new decorative techniques and styles deriving from the Roman Provinces (Aufderhaar, 2005: 122ff).

\section{References}

Adomat, A., 2000. Die drei Prachtfibeln von Skovgårde, in P. Ethelberg (ed.), Skovgårde. Ein Bestattungsplatz mit reichen Frauengräbern des 3. Jhs. n. Chr. auf Seeland. Nordiske Fortidsminder Serie B 19. Kopenhagen, Det Kongelige Nordiske Oldskriftselskab, 409-413.

Almgren, O., 1973. Studien über Nordeuropäische Fibelformen der ersten christlichen Jahrhunderte mit Berücksichtigung der provinzialrömischen und südrussischen Formen. MannusBibliothek 32. Bonn, Kabitz.

Andersson, K., 1995. Romatida guldsmide i Norden III. Övriga smycken, teknisk analys och verkstadgrupper. AUN 21. Uppsala, Societas Archaeologica Upsaliensis.
ANHeuSER, K., 1999. Im Feuer vergoldet. Geschichte und Technik der Feuervergoldung und der Amalgamversilberung. AdRSchriftenreihe zur Restaurierung und Grabungstechnik 4. Stuttgart: Theiss.

Arrhenius, B., 1964. Patinering och kolorering, in W. Holmqvist (ed.), Nordiskt guldsmide under järnåldern. Stockholm, Historiska Museet, 38-40.

ArrhenIUs, B. 1968. Sveagold und Wikingerschmuck. Römisch Germanisches Zentralmuseum Mainz Ausstellungskataloge 3. Mainz, Römisch Germanisches Zentralmuseum.

AufderhaAR, I., 2005. Die Vergoldung im ersten Jahrtausend nach Christus. Technologien und ihre Relevanz im archäologischen Kontext untersucht anhand ausgewählter Fundgruppen. Unpublished Magisterthesis, University of Münster, Germany.

AufderhaAr, I., 2009. Zu Entwicklungen in der Vergoldungstechnik im germanischen Raum während des 1 . Jahrtausends nach Christus. Restaurierung und Archäologie 2: 31-46.

Aufleger, M., 1996. Metallarbeiten und Metallverarbeitung, in A. Wieczorek, P. Perin, K. von Welck, W. Menghin (eds.), Die Franken. Wegbereiter Europas 2. Mainz, Philipp von Zabern, 618-628.

BeCKer, M., 2001. Bekleidung - Schmuck - Ausrüstung, in S. Fröhlich (ed.), Gold für die Ewigkeit. Das germanische Fürstengrab von Gommern. Landesamt für Archäologie Sachsen-Anhalt. Halle, Landesmuseum für Vorgeschichte, 127-147.

BeCKer, M., 2002A. Ein Germanenschild unter dem Mikroskop. Archäologie in Deutschland 6: 28-29.

BeCKer, M., 2002в. Der Fund des Monats Oktober 2002. Der Schild des Fürsten von Gommern. Germanische Kunst und Römische Beute (?) aus einem Grab des 3. Jahrhunderts. From: www.archlsa.de/funde-der-monate/10.02/, 12/2004.

Becker, M., Füting, M. and Schnarr, H., 1996A. Vergoldete Silberpreßbleche der römischen Kaiserzeit aus materialkundlicher und technologischer Sicht, in S. Ostritz, R. Einicke (eds.), Terra \& Praehistoria. Festschrift Klaus-Dieter Jäger. Beiträge zur Ur- und Frühgeschichte Mitteleuropas 9. Wilkau-Hasslau, Beier \& Beran, 99-106.

Becker, M., Füting, M. and Schnarr, H., 1996в. Mikroskopische und mikroanalytische Untersuchungen an Fundstücken aus dem „Fürstengrab“ von Gommern, Ldkr. Jerichower Land. Zweiter Teil. Jahresschrift für mitteldeutsche Vorgeschichte 78: 37-62.

BeCKer, M., 1998. Römische und germanische Bunt- und Edelmetallfunde im Vergleich. Archäometallurgische Untersuchungen ausgehend von elbgermanischen Körpergräbern. Bericht der Römisch-Germanischen Kommission 79: 204-216. 
Böнme, H.W., 1974. Germanische Grabfunde des 4. bis 5. Jahrhunderts zwischen unterer Elbe und Loire. Studien zur Chronologie und Bevölkerungsgeschichte. Münchner Beträge zur Vor- und Frühgeschichte 19. München, Beck.

Bölскоw, В., 2006. Quern-Scheersberg. Ein Friedhof im Feld, in R.-M. Weiss, W. Marnette (eds.), Frühes Gold aus Norddeutschland. Veröffentlichungen des Helms-Museums für Archäologie und die Geschichte Hamburgs 96. Hamburg, Helms-Museum, 66-67.

Brandt, J., 2006. Fürstenschmuck aus der Schublade. Die Scheibenfibel von Tangendorf, in R.-M. Weiss, W. Marnette (eds.), Frühes Gold aus Norddeutschland. Veröffentlichungen des Helms-Museums für Archäologie und die Geschichte Hamburgs 96. Hamburg, Helms-Museum, 70-71.

Brepohl, E., 1987. Theophilius Presbyter und die mittelalterliche Goldschmiedekunst. Wien, Köln, Graz, Böhlau.

Brepoht, E., 2003. Theorie und Praxis des Goldschmieds. Leipzig and Köln, Fachbuchverlag.

Bruns, D., 2003. Germanic Equal Arm Brooches of the Migration Period. A study of style, chronology and distribution including a full catalogue of finds and contexts. BAR International Series 1113. Oxford, Archaeopress.

BühleR, B., 1998/99. Untersuchungen zu Guß, Oberflächenbearbeitung und Vergoldung an frühmittelalterlichen Bunt- und Edelmetallgegenständen. Archaeologia Austriaca. Beiträge zur Paläanthropologie, Ur-und Frühgeschichte Österreichs 82/83: 429-478.

Caley, E.R., 1926. The Leyden Papyrus X. An English Translation with brief notes. Journal of Chemical Education 2: 1149-1166.

von Carnap-Bornheim, C., 1994. Zur Entwicklung des germanischen Gold- und Silberschmiedehandwerks vor und nach den Markomannenkriegen -Vergoldung, Filigran und Pressblech, in H. Friesinger, J. Tejral, A. Stuppner (eds.), Markomannenkriege. Ursachen und Wirkung. VI. Internationales Symposium "Grundprobleme der frühgeschichtlichen Entwicklung im nördlichen Mitteldonaugebiet". Brno, Archäologisches Institut der Akademie der Wissenschaften der Tschechischen Republik, 99-107.

von Carnap-Bornheim, C., 1998. Übernahme und Verbreitung innovativer Techniken und Verzierungsgewohnheiten bei germanischen Fibeln, in J. Kunow (ed.), 100 Jahre Fibelformen nach Oscar Almgren. Forschungen zur Archäologie im Land Brandenburg 5. Wünsdorf, Verlag Brandenburgisches Landesmuseum für Ur- und Frühgeschichte, 467-473.

von Carnap-Bornheim, C., 2006. Mehr Schein als Sein, oder: Vergoldung in der Römischen Kaiserzeit im germanischen Barbaricum, in R. Bleile (ed.), Magischer Glanz. Gold aus archäologischen Sammlungen Norddeutschlands. Schleswig: Archäologisches Landesmuseum in der Stiftung SchleswigHolsteinische Landesmuseen Schloß Gottorf, 88-92.
Cosack, E., 1979. Die Fibeln der Älteren Römischen Kaiserzeit in der Germania libera (Dänemark, DDR, BRD, Niederlande, CSSR). Eine technologisch-archäologische Analyse. Teil I. Armbrustfibeln, Rollenkappenfibeln, Augenfibeln. Neumünster, K. Wacholz.

Drescher, H., 1955. Die Nachbildung der Scheibenfibel aus Tangendorf, Kreis Harburg. Die Kunde 5: 25-33.

EberT, M., 1929. Vergolden. Reallexikon der Vorgeschichte 14. Berlin and New York: De Gruyter, 131-132.

EgGers, H.J., 1964. Die Kunst der Germanen in der Eisenzeit, in H.J. Eggers, E. Will, R. Joffroy, W. Holmqvist (eds.), Kelten und Germanen in heidnischer Zeit. Kunst der Welt. Ihre geschichtlichen, soziologischen und religiösen Grundlagen. BadenBaden, Holle, 5-87.

EgGERs, H.J., 1974. Einführung in die Vorgeschichte. München, R. Piper \& Co Verlag.

Eichнorn, G., 1908. Der Grabfund zu Dienstedt bei Remda. Zeitschrift für Ethnologie 40: 902-914.

EthelberG, P., 2000. Skovgårde. Ein Bestattungsplatz mit reichen Frauengräbern des 3. Jhs. n. Chr. auf Seeland. Nordiske Fortidsminder Serie B 19. Kopenhagen, Det Kongelige Nordiske Oldskriftselskab.

Franke, H., 1987. Zur Herstellung der Kerbschnittfibel von Groß-Köris, Kr. Königs Wusterhausen. Veröffentlichungen des Museums für Ur-und Frühgeschichte Potsdam 23: 237-241.

Frick, H.J., 1992/1993. Karolingisch-ottonische Scheibenfibeln des nördlichen Formenkreises. Offa 49: 243-463.

Fütıng, M., 2001. Wo der Augenschein versagt - Mikroanalysen am archäologischen Objekt, in S. Fröhlich (ed.), Gold für die Ewigkeit. Das germanische Fürstengrab von Gommern. Halle, Landesamt für Archäologie Sachsen-Anhalt - Landesmuseum für Vorgeschichte, 164-167.

Göldner, H., 1987. Studien zu Rhein- und Moselfränkischen Bügelfibeln I. Marburger Studien zur Vor- und Frühgeschichte 8-1. Marburg, Hitzeroth.

Gustavs, S., 1987. Silberschmuck, Waffen und Siedlungsbefunde des 3. bis 5. Jh. u. Z. aus einem See bei Groß Köris, Kr. Königs Wusterhausen. Veröffentlichungen des Museums für Ur-und Frühgeschichte Potsdam 23: 215-236.

Halleux, R., 2002. Les Alchimistes Grecs. Papyrus de Leyde, Papyrus de Stockholm, Recettes. Paris, Les Belles Lettres.

Hammer, P., 1998. Verfahrenstechnische Untersuchungen. Berichte der Römisch-Germanischen Kommission 79: 179-199.

Hammer, P. and Voss, H.-U., 1998. Glossar metallkundlicher und herstellungstechnischer Fachbegriffe - erläutert für antike Handwerkstechnik. Bericht der Römisch-Germanischen Kommission 79: 314-330.

Hartmann, A. and Wolf, R., 1975. Vergleichende Spektralanalysen an einigen frühmittelalterlichen Goldfunden und Goldblattkreuzen, in W. Hübener (ed.), Die 
Goldblattkreuze des frühen Mittelalters. Veröffentlichungen des Alemannischen Institutes Freiburg i.Br. 37. Bühl, Konkordia.

Haselhoff, G., 1979. Römische Elemente in sächsischem Schmuck (am Beispiel der gleicharmigen Fibeln), in C. Ahrens (ed.), Sachsen und Angelsachsen. Veröffentlichungen des HelmsMuseums für Archäologie und die Geschichte Hamburgs 32. Hamburg, Helms-Museum, 153-161.

HaSelHOFF, G., 1990. Email im frühen Mittelalter. Frühchristliche Kunst von der Spätantike bis zu den Karolingern. Marburger Studien zur Vor- und Frühgeschichte Sonderband 1. Marburg, Hitzeroth.

Jansson, I., 1984A. Kleine Rundspangen, in G. Arwidsson (ed.), Birka II:1. Systematische Analysen der Gräberfunde. Stockholm, Almqvist \& Wiksell, 58-74.

Jansson, I., 1984B. Kleine Rundspangen, in G. Arwidsson (ed.), Birka II:1. Systematische Analysen der Gräberfunde. Stockholm, Almqvist \& Wiksell, 75-84.

JANSSON, I., 1985. Ovala spännbucklor. En studie av vikingatida standardsmycken med utgångspunkt frän Björkö-fynden. AUN 7. Uppsala, Societas Archaeologica Upsaliensis.

Jørgensen, L. and Vang Petersen, P., 1998. Guld, magt og tro. Danske guldskatte for oldtid og middelalder. = Gold, power, belief. Danish gold treasures from Prehistory and the Middle Ages. Kopenhagen, Nationalmuseet.

Kent, J.P.C., 1972. Gold Standards of the Merovingian Coinage, A.D. 580-700, in E.T. Hall (ed.), Methods of Chemical and Metallurgical Investigations of Ancient Coinage. Royal Numismatic Society Special Publication 8. London, Royal Numismatic Society, 69-74.

Klein-Pfeuffer, M., 1993. Merowingerzeitliche Fibeln und Anhänger aus Preßblech. Marburger Studien zur Vor- und Frühgeschichte 14. Marburg, Hitzeroth.

Косн, А., 1998. Bügelfibeln der Merowingerzeit im westlichen Frankenreich. Monographien des Römisch-Germanischen Zentralmuseums, Forschungsinstitut für Vor- und Frühgeschichte 41, 1 und 2. Mainz, Verlag des RömischGermanischen Zentralmuseums.

KüHN, H., 1981. Die germanischen Bügelfibeln der Völkerwanderungszeit in Mitteldeutschland. Akademische Druck- und Verlagsanstalt,Graz.

KyHlberg, O., 1986. Late Roman and Byzantine Solidi. An archaeological analysis of coins and hoards, in A. Lundström, H. Clarke (eds.), Excavations at Helgö X. Coins, Gold and Iron. Stockholm, Almqvist \& Wiksel, 13-126.

Lins, P.A. and OdDY, W.A., 1975. The Origins of Mercury Gilding. Journal of Archaeological Science 2: 365-373.

LippmanN, E. von, 1919. Entstehung und Ausbreitung der Alchemie. Berlin, Springer.

Lund Hansen, U., 1971. Blik- og glasornamenterede Fibler af Mackeprang Type IX. Aarbøger for nordisk Oldkyndighet og Historie 1971: 72-119.
Lund Hansen, U., 1987. Römischer Import imNorden. Warenaustausch zwischen dem Römsichen Reich und dem freien Germanien während der Kaiserzeit unter besonderer Berücksichtigung Nordeuropas. Nordiske Fortidsminder Serie B 10. Kopenhagen, Det Kongelige Nordiske Oldskriftselskab.

Lund Hansen, U., 1995. Himlingøje - Seeland - Europa. Ein Gräberfeld der jüngeren römischen Kaiserzeit aus Seeland, seine Bedeutung und internationalen Beziehungen. Nordiske Fortidsminder Serie B 13. Kopenhagen, Det Kongelige Nordiske Oldskriftselskab.

Nørling-Christensen, H., 1942. Une trouvaille de parures de l'ancien âge du fer romain faite a Vester-Mellerup, Vendsyssel. Acta Archaeologica 13: 332-355.

ODd, W.A. 1993. Gilding of Metals in the Old World, in Metal Plating and Patination, S. La Niece and P. Craddock (eds.), Butterworth-Heinemann Ltd, Oxford, 171-181.

Oddy, W.A., La Niece, S., Curtis, J.E. and Meeks, N.D., 1981. Diffusion-bonding as a Method for Gilding in Antiquity. MASCA Journal 1(8): 239-241.

Oldeberg, A., 1943. Metallteknik under förhistorisk tid II. Stockholm, Viktor Pettersons Bokindustri AB.

Oldeberg, A., 1966. Metallteknik under vikingatid och medeltid. Stockholm: Viktor Pettersons Bokindustri AB.

Plather, U., Astrup, E. and Straume, E., 1995. Norwegian rosette-brooches of the $3^{\text {rd }}$ century AD: their construction, materials and technique. Historical Metallurgy 29(1): 12-24.

Plather, U. and Simensen, C.J., 2002. Some characteristic features of gilded jewellery from the 3rd, 5 th and 8 th centuries found in Norway. Germania 80: 547-570.

RademaCHer, F., 1940. Fränkische Goldscheibenfibeln aus dem rheinischen Landesmuseum in Bonn. München, Bruckmann.

Raub, C., 1993. How to coat objects with gold - Pliny, Leyden Papyrus X, Mappae Clavicula and Theophilius seen with a modern chemist's eyes, in C. Eluère (ed.), Outils et ateliers d'orfevres des temps anciens. Antiquités nationales mémoire 2. Saint-Germain-en-Laye: Société des Amis du Musée des Antiquités Nationales et du château de Saint-Germain-en Laye, 101-110.

Riederer, J., 1987. Archäologie und Chemie - Einblicke in die Vergangenheit. Berlin, Rathgen-Forschungslabor.

RoggenbucK, P., 1988. Untersuchungen zu den Edelmetallfunden der römischen Kaiserzeit zwischen Limes, Nord-und Ostsee. BAR International Series 449. Oxford, Archaeopress.

Rотн, H., 1986. Kunst und Handwerk im frühen Mittelalter. Archäologische Zeugnisse von Childerich I. bis zu Karl dem Großen. Stuttgart, Theiss.

Siegmund, F., 1998. Gold. Reallexikon der Germanischen Altertumskunde 12. Berlin and New York, De Gruyter, 308312. 
Thieme, B., 1978. Filigranscheibenfibeln der Merowingerzeit aus Deutschland. Bericht der Römisch-Germanischen Kommission 59: 381-500.

Thörle, S., 1998. Formen und Verzierungen gleicharmiger Bügelfibeln im westlichen Frankenreich. Acta Praehistorica et Archaeologica 30: 106-112.

THÖRLE, S., 2001. Gleicharmige Bügelfibeln des frühen Mittelalters. Universitätsforschungen zur prähistorischen Archäologie 81 . Bonn, Habelt.

Thомаs, S., 1966. Die germanischen Scheibenfibeln der Römischen Kaiserzeit im freien Germanien. Berliner Jahrbuch für Vor-und Frühgeschichte 6: 1-187.

VIELITZ, K., 2003. Die Granatscheibenfibeln der Merowingerzeit. Europe médiévale 3. Montagnac, Mergoil.

Voss, H.-U., Hammer, P. and Lutz, J., 1998. Römische und germanische Bunt und Edelmetallfunde im Vergleich. Bericht der Römisch-Germanischen Kommission 79: 107-382.
WeIsGerber, G., 2003. Quecksilber. Reallexikon der Germanischen Altertumskunde 24. Berlin and New York, De Gruyter, 9-11.

WeIsGerber, G., 2007. Zinnober. Reallexikon der Germanischen Altertumskunde 34. Berlin and New York, De Gruyter, 572573.

Werner, J., 1981. Zu einer elbgermanischen Fibel des 5. Jahrhunderts aus Gaukönigshofen, Ldkr. Würzburg. Ein Beitrag zu den Fibeln vom „Typ Wiesbaden“ und zur germanischen Punzornamentik. Bayerische Vorgeschichtsblätter 46: 225-254.

Wolters, J., 1981. Der Gold- und Silberschmied 1. Werkstoffe und Materialien. Stuttgart, Rühle-Diebener Verlag GmbH. 
